\title{
Correction to: E-cigarettes: harm reduction or rehabilitation of the tobacco industry?
}

\section{Wasim Maziak ${ }^{1}$}

Published online: 21 January 2020

(C) Swiss School of Public Health (SSPH+) 2020

\section{Correction to: International Journal of Public Health} https://doi.org/10.1007/s00038-019-01316-y

In the above paper, authors stated mistakenly that Philip Morris International acquired $35 \%$ of JUUL shares, while Altria, the parent company of Philip Morris USA, made that acquisition, and that IQOS is an e-cigarette, while it is considered by the FDA as a heat-not-burn tobacco device.
Hence, line 13 of section "Good industry/bad industry" should read as"......Altria (owner of Philip Morris USA) to acquire $35 \%$ of their shares...".

Publisher's Note Springer Nature remains neutral with regard to jurisdictional claims in published maps and institutional affiliations.

The original article can be found online at https:// doi.org/10.1007/s00038-019-01316-y.

Wasim Maziak

wmaziak@fiu.edu

1 Department of Epidemiology, Robert Stempel College of Public Health and Social Work, Florida International University, Miami, FL 33199, USA 